\title{
Microbial contamination level and microbial diversity of occupational environment in commercial and traditional dairy plants
}

\author{
Agata Stobnicka-Kupiec ${ }^{1, A-D \oplus}$, Małgorzata Gołofit-Szymczak ${ }^{1, B \oplus}$, Rafał Górny, ${ }^{1, E-F} \oplus$ \\ ${ }^{1}$ Central Institute for Labour Protection - National Research Institute, Warsaw, Poland \\ A - Research concept and design, B - Collection and/or assembly of data, C - Data analysis and interpretation, \\ $D$ - Writing the article, $E$ - Critical revision of the article, $F$ - Final approval of article
}

Stobnicka-Kupiec A, Gołofit-Szymczak M, Górny R. Microbial contamination level and microbial diversity of occupational environment in commercial and traditional dairy plants. Ann Agric Environ Med. 2019; 26(4): 555-565. doi: 10.26444/aaem/112381

\begin{abstract}
I Abstract
Objective. The aim of this study was to assess microbial contamination of the air and surfaces at workplaces in commercial (CD) and traditional (TD) dairies.

Materials and method. Bioaerosol (impactor) and surface (swab) samples were collected in CD and in TD. Bacterial and fungal concentrations in the air and on surfaces were calculated and all isolated microorganisms taxonomically identified, based on their morphological, biochemical and molecular features.

Results. Average concentrations of bacterial aerosol ranged between $70-860 \mathrm{CFU} / \mathrm{m}^{3}$ and $265-14639 \mathrm{CFU} / \mathrm{m}^{3}$, while for fungal aerosol were between $50-290 \mathrm{CFU} / \mathrm{m}^{3}$ and $55-480 \mathrm{CFU} / \mathrm{m}^{3}$ in CD and TD, respectively. Average bacterial concentrations on surfaces ranged between $1.0-49.7 \mathrm{CFU} / \mathrm{cm}^{2}$ and $0.2-60.4 \mathrm{CFU} / \mathrm{cm}^{2}$, whereas average fungal surface contamination ranged between 0-2.7 CFU/ $\mathrm{cm}^{2}$ and $0-4.6 \mathrm{CFU} / \mathrm{cm}^{2}$ in CD and TD, respectively. Qualitative analysis revealed mainly the presence of saprophytic microorganisms; however, several pathogenic strains (Staphylococcus aureus, Streptococcus intermedius, Clostridium perfringens, Actinomyces spp., Streptomyces spp., Candida albicans) were also isolated from both the air and surface samples in the studied dairies.

Conclusions. The air and surfaces in TD were more polluted than those in CD; however, in both types of dairies, the levels of microbial contaminants did not exceed respective threshold limit values. Nevertheless, the presence of pathogenic microorganisms may increase health risk for dairy workers and influence the quality of products. Hence, proper hygienic measures should be introduced and performed to guarantee high microbial quality of both production processes and milk products.
\end{abstract}

\section{Key words}

occupational exposure, bacteria, fungi, bioaerosols, surface swabs, dairy plants

\section{INTRODUCTION}

On a world scale, the dairy sector plays an important economic role in providing jobs for rural communities. According to the International Dairy Federation [1], the number of people employed in the dairy industry is about to 200,000 in Russia, 230,000 in China, and 500,000 in Egypt. In this branch of industry, the presence of microorganisms is an immanent part of many production processes. In the dairy industry, microorganisms can play both a positive role in the food production system and a negative one, causing contamination of the working environment.

The variety of factors that may affect food safety has led to the development of several management systems as Good Hygienic Practice (GHP), Good Manufacturing Practice (GMP), Hazard Analysis Critical Control Points (HACCP) system, etc. Their main task is to ensure that the resulting food product will be safe for the consumers [2]. Their use allows, among others, pollution control (including biological contaminants) for the ready-to-consume products and consumer safety, without neglecting the safety of the workers involved in the production processes.

Address for correspondence: Agata Stobnicka-Kupiec, Central Institute for Labour Protection - National Research Institute, Poland

E-mail: agsto@ciop.pl

Received: 29.08.2019; accepted: 16.09.2019; first published: 30.09.2019
Raw milk, even when milking is performed under aseptic conditions, is microbiologically contaminated. Microorganisms can enter the raw milk from the cowshed bedding, fodder, animal skin and hair and milking equipment, as well as via the clothes and hands of the workers [3]. Milk, being rich in nutrients such as proteins, lipids and sugars, provides an ideal environment for the growth of various microorganisms [4]. Natural milk microbiota is composed primarily of lactic acid bacteria (LAB); however, the presence of milk-borne bacteria and fungi responsible for human infections is also possible $[5,6]$. The list of bacteria that can cause milk contamination is long and usually includes: Campylobacter jejuni, Bacillus cereus, Escherichia coli (including Shiga toxin strains), Coxiella burnetii, Mycobacterium spp., Salmonella spp. (including Salmonella Typhi), Yersinia enterocolitica, Pseudomonas aeruginosa, Corynebacterium spp., Clostridium perfringens, Nocardia spp. and Staphylococcus aureus strains, including those producing heat-stable toxins $[4,7]$. Raw milk may also contain yeasts from Candida, Cryptococcus, Pichia, Debaryomyces, Geotrichum, Kluyveromyces, Rhodotorula, Trichosporon, Saccharomyces, and Yarrowia genera as well as molds from Aspergillus, Chrysosporium, Cladosporium, Engyodontium, Fusarium, Penicillium, and Mucor genera $[8,9,10]$.

Although both the Food and Drug Administration (FDA) and Centers for Disease Control and Prevention (CDC) in 
the USA recommend the pasteurization of milk intended for human consumption $[11,12]$, many dairy products like cheese, butter or cream are still made from raw (unpasteurized) milk, especially in traditional dairies. As many consumers clearly demand and expect the food manufactured from 'highquality raw materials' [13], this type of market pressure may result in increased risk for dairy workers [14, 15].

Dairy workers can be exposed not only to saprophytic and pathogenic microbiota from raw milk, but also to starter cultures of selected bacterial and fungal strains. Such cultures being added during milk processing support fermentation and/or food preservation processes lead to the improvement of texture, flavour, and nutritional value of dairy products [16]. The most popular starter cultures are lactic acid bacteria (LAB), such as Lactococcus lactis, Lactobacillus delbrueckii, Leuconostoc mesenteroides or Streptococcus thermophilus. There are also selected mould strains used for ripened cheese production, including Penicillium roqueforti, Penicillium camemberti, and Penicillium candidum $[17,18]$. According to the FDA, starter cultures are clearly classified as Generally Recognized As Safe (GRAS) [11, 19]. However, GRAS status applies to the use in food production only, and information about health effects of airborne and dermal exposure to GRAS strains is still very scarce. So far, few publications have proved that workers from occupational areas with high levels of airborne LAB reported more health symptoms (e.g. irritations and immune system responses), compared to control groups $[20,21]$.

\section{OBJECTIVE}

Data regarding bioaerosols in dairy barns is available $[22,23]$; however, information about microbial diversity and concentration in bioaerosols and on surfaces in the occupational environment of dairy plants are still scarce. Taking the above into account, the aim of this study was to perform the complex quantitative and qualitative characterization of microbiological agents in the air and on surfaces at workplaces in commercial and traditional dairies, to provide important information for proper occupational risk assessment and occupational risk management for workers in dairies.

\section{MATERIALS AND METHOD}

Environmental field samples. Bioaerosol and surface swab samples were collected in three commercial and three traditional dairy plants located in the central and eastern regions of Poland during summer 2018 (June-August). The examined dairy plants represented typical dairies of the sector of small and medium enterprises, and specialized in milk, butter, cream, yoghurt and cheese (excluding mouldripened cheese) production. The samples were collected both in commercial dairies (CD) with an almost fully automated production process, and in traditional dairies (TD) where many production activities were manually performed. The buildings of each type of dairy plant were differentiated, taking into account the type and characteristics (size, type of ventilation), number of workers, methods of production (automatic, manual, mixed), nearby presence of animals (dairy cattle), and type of processed milk (raw, pasteurized).
Table 1 shows the buildings of commercial and traditional dairy plants with their detailed characteristic. To evaluate the potential influence of external microbial pollution sources on air quality at the studied workplaces, background air (atmospheric bioaerosol) samples were simultaneously collected in close vicinity (approximately $300 \mathrm{~m}$ from the border) of the studied dairies.

Table 1. Description of the commercial and traditional dairy plant buildings

\begin{tabular}{lll}
\hline $\begin{array}{l}\text { Type of dairy plant } \\
\text { Characteristic }\end{array}$ & Commercial & Traditional \\
\hline Size & $>2,000 \mathrm{~m}^{2}$ & $\sim 200-300 \mathrm{~m}^{2}$ \\
\hline Type of ventilation & mechanical & natural \\
\hline Number of workers & $160-250$ & $2-10$ \\
\hline Method of production & $\begin{array}{l}\text { fully automated } \\
\text { (excluding packaging) }\end{array}$ & $\begin{array}{l}\text { manual or mixed (semi- } \\
\text { automatic) }\end{array}$ \\
\hline $\begin{array}{l}\text { Nearby presence of } \\
\text { animals (cattle) }\end{array}$ & no & $\begin{array}{l}\text { yes (milk reception area in } \\
\text { neighborhood with milking } \\
\text { area) }\end{array}$ \\
\hline Type of processed milk & pasteurized & raw \\
\hline
\end{tabular}

All samples were collected after obtaining the appropriate permits issued by CD and TD authorities.

Bioaerosol sampling. In the examined dairies, bioaerosol samples were collected during regular work hours at the following workplaces: milk reception, milk storage, cheese production, cream and butter production, and packaging area. Bioaerosol samples (100 L) were collected using properly calibrated MAS impactor (model 100-NT, Merck Eurolab $\mathrm{GmbH}$, Darmstadt, Germany) on appropriate agar media: trypticase soy agar (TSA) with 5\% of defibrinated sheep blood (bioMérieux, Marcy-l'Étoile, France) for mesophilic bacteria, MRS agar (agar De Man, Rogosa and Sharpe, bioMérieux) for lactic acid bacteria, Schaedleragar (SCS, bioMérieux), with $5 \%$ of defibrinated sheep blood for anaerobic bacteria, and malt-extract agar (MEA, Oxoid, UK) for fungi. All air samples were collected at the height of 1-1.5 $\mathrm{m}$ above the floor or ground simulating aspiration from the human breathing zone $[24,25]$.

During bioaerosol measurements, temperature and relative humidity of the air were measured with a portable thermohygrometer (model TFA 30.5024, Conrad Electronic GmbH, Hirschau, Germany).

Surface swab sampling. Surface samples of $100 \mathrm{~cm}^{2}$ area (limited by the use of $10 \times 10 \mathrm{~cm}$ sterile template) were collected with sterile swabs (Copan, Brescia, Italy) from worktops within the milk reception zone, surfaces of tanks within the milk storage area, worktops in the cheese production zone, worktops within the cream and butter production area, and from conveyer belts within the packaging area.

After shaking the swabs for 30 minutes at room temperature, a series of dilutions for each sample was prepared $\left(10^{-1}-10^{-3}\right)$ and used in triplicates in the amount of $0.1 \mathrm{~mL}$ for inoculation of proper medium (see above) for each examined group of microorganisms.

Laboratory analysis. Agar plates with bioaerosol and surfaces swab samples were incubated in the following conditions: 1 day $\left(37^{\circ} \mathrm{C}\right)+3$ days $\left(22^{\circ} \mathrm{C}\right)+3$ days $\left(4^{\circ} \mathrm{C}\right)$ for mesophilic 
bacteria, 3 days $\left(37^{\circ} \mathrm{C}\right)$ in anaerobic condition for lactic acid bacteria, 3 days $\left(37^{\circ} \mathrm{C}\right)+2$ days $\left(30^{\circ} \mathrm{C}\right)$ in anaerobic condition for anaerobic bacteria and 4 days $\left(30^{\circ} \mathrm{C}\right)+4$ days $\left(22^{\circ} \mathrm{C}\right)$ for fungi [26]. The final concentration of microorganisms in bioaerosol was determined as colony forming units per $1 \mathrm{~m}^{3}$ of air $\left(\mathrm{CFU} / \mathrm{m}^{3}\right)$, while on surfaces as CFU per $100 \mathrm{~cm}^{2}$ $\left(\mathrm{CFU} / 100 \mathrm{~cm}^{2}\right)$.

All isolated microbial colonies were then classified to the genus and/or species level, taking into account their macroscopic and microscopic features. Bacterial and yeast strains identification was supplemented with proper biochemical (API) tests (bioMérieux). Filamentous fungi were identified based on their macro- and micromorphology with proper taxonomic keys [27, 28, 29, 30]. The most prevalent microbial isolates were also analyzed by molecular polymerase chain reaction, followed by random amplification of polymorphic DNA method (RAPD-PCR) [31]. Bacterial and fungal DNA was isolated from pure cultures using Qiamp DNA Mini Kit (Qiagen, Hilden, Germany) for bacteria and Fungi DNA Mini Kit (Syngen Biotech, Wrocław, Poland) for mulds and yeasts. The isolated bacterial DNA was amplified in PCR reactions with BAK11w (5'-AGTTTGATCMTGGCTCAG-3') and BAK2 (5'-GGACTACHAGGGTATCTAAT-3') primers for amplification of bacterial 16S rRNA gene fragment adequate to $E$. coli $16 \mathrm{~S}$ rRNA gene positions from 10-806. In turn, the isolated fungal DNA was amplificated in PCR reactions with ITS1 (5'-TCCGTAGGTGAACCTGCGG-3') and ITS4 (5'-TCCTCCGCTTATTGATATGC-3') primers for amplification of fungal genome fragment located between 18S-28S rRNA genes of ITS1, 5.8S rRNA, and ITS2 fragments. PCR products were then purified and sequenced with ABI3730 Genetic Analyzer (Applied Biosystems, Waltham, USA). Comparison of DNA fragments to GeneBank database (National Center for Biotechnology Information, National Library of Medicine, USA) was performed using BLAST algorithm (Basic Local Alignment Search Tool) [32, $33,34]$.

Statistical analysis. The obtained results were statistically analyzed with Kruskal-Wallis and Mann-Whitney tests using STATISTICA, version 7.1 (StatSoft Inc., Tulsa, USA). P values below 0.05 were considered statistically significant.

\section{RESULTS}

Quantitative analysis of bioaerosol samples. Average concentrations of bacterial and fungal aerosols in commercial and traditional dairies are shown in Table 2. Statistical analysis showed that bacterial aerosol concentrations were statistically higher at workplaces in TD than in $\mathrm{CD}(\mathrm{p}<0.05)$.

Table 2. Bacterial and fungal aerosol concentrations $\left(\mathrm{CFU} / \mathrm{m}^{3}\right)$ in commercial (CD) and traditional (TD) dairies

\begin{tabular}{lcccc}
\hline \multirow{2}{*}{ Type of dairy } & \multicolumn{2}{c}{ Bacteria } & \multicolumn{2}{c}{ Fungi } \\
\cline { 2 - 5 } & Median & Range & Median & Range \\
\hline CD & 265 & $40-980$ & 165 & $40-390$ \\
\hline TD & 2345 & $200-26620$ & 230 & $20-530$ \\
\hline Atmospheric background near CD & 165 & $90-130$ & 1130 & $980-1280$ \\
\hline Atmospheric background near TD & 780 & $760-800$ & 1280 & $1230-1330$ \\
\hline
\end{tabular}

At the same time, the concentration of bacterial aerosols in TD and CD were significantly higher than those measured in the atmospheric background near the studied dairies $(\mathrm{p}<0.05)$. The concentration of fungal aerosols revealed an opposite relationships being significantly lower than those measured in the atmospheric background $(\mathrm{p}<0.05)$.

Concentrations of bacterial and fungal aerosols at the studied workplaces in dairies are shown in Table 3. Average concentrations of bacteria in $\mathrm{CD}$ ant TD ranged between 70-860 CFU $/ \mathrm{m}^{3}$ and $265-14639 \mathrm{CFU} / \mathrm{m}^{3}$, respectively. Average concentrations of fungi in $\mathrm{CD}$ and TD ranged between $50-290 \mathrm{CFU} / \mathrm{m}^{3}$ and $55-480 \mathrm{CFU} / \mathrm{m}^{3}$, respectively. The highest concentrations of microbial aerosols in both types of studied dairies were detected within the milk reception zone. However, despite of existing variations in bioaerosol concentrations, the Kruskal-Wallis test did not show statistically significant differences between the studied workplaces $(\mathrm{p}>0.05)$.

Within the tested processing areas, the air temperature ranged between $23.3-24.7^{\circ} \mathrm{C}$, while relative humidity between $34.9-55.1 \%$. Neither air temperature, nor the relative humidity significantly influenced the bacterial and fungal aerosol concentrations ( $\mathrm{p}>0.05)$.

Qualitative analysis of bioaerosol samples. Percentage distributions of microbial groups identified in bioaerosols in the studied dairies and in the atmospheric air are shown in Figure 1. In bioaerosol collected in $\mathrm{CD}$, non-sporing Gram-positive rods (including LABs) were predominant, accounting for $46.3 \%$ of total microbiota, followed by Gram-positive cocci (24.8\%). Fungi, Gram-positive bacilli and mesophilic actinomycetes constituted $18.9 \%, 9.6 \%$ and $0.4 \%$ of the total microbiota, respectively. In TP, the most numerous were Gram-positive cocci (38.3\%), followed by non-sporing Gram-positive rods (including LABs; 30.5\%). Fungi, Gram-positive bacilli and mesophilic actinomycetes constituted $15.5 \%, 14.7 \%$ and $1.0 \%$ of the total microbiota, respectively. In the atmospheric air, fungi were the most abundant group of isolated microorganisms (55.5\% of total isolated microbiota).

All bacterial and fungal strains isolated from the air of the studied dairies, with their percentages in relation to the total microbiota, are listed in Table 4.18 bacterial species belonging to 9 genera were isolated in CD and 27 bacterial species belonging to 10 genera were isolated in TD. Bifidobacterium representatives were the most frequently isolated bacteria in CD (17.8\%) and TD (15.6\%), followed by Lactobacillus paracasei ssp. paracasei (9.7\%) in CD and by Streptococcus thermophilus (11.5\%) in TD. In case of fungi, 12 species belonging to 5 genera were isolated in CD and 19 species belonging to 8 genera were isolated in TD. In both types of dairies, the most frequently isolated moulds belonged to the Penicillium genus. Bioaerosol sampling also revealed the presence of yeast strains, among which the most frequently isolated was Geotrichum candidum, constituting $2.7 \%$ and $1.3 \%$ of isolated microbiota in $\mathrm{CD}$ and $\mathrm{TD}$, respectively.

Biological agents from risk group 2 (according to the classifications in Directive 2000/54/EC and in Ordinance of the Polish Minister of Health) $[35,36]$ were also detected among isolated microorganisms. In CD, Actinomyces spp. constituted $0.4 \%$, while in TD Staphylococcus aureus and Streptomyces spp. contributed to $4.5 \%$ and $1 \%$ of total microbiota. 
Table 3. Concentrations of bacteria and fungi $\left(\mathrm{CFU} / \mathrm{m}^{3}\right)$ at the studied workplaces in commercial (CD) and traditional (TD) dairies

\begin{tabular}{|c|c|c|c|c|c|c|c|c|}
\hline \multirow{3}{*}{ Workplace } & \multicolumn{4}{|c|}{ Bacteria } & \multicolumn{4}{|c|}{ Fungi } \\
\hline & \multicolumn{2}{|c|}{$C D$} & \multicolumn{2}{|c|}{ TD } & \multicolumn{2}{|c|}{$C D$} & \multicolumn{2}{|c|}{ TD } \\
\hline & Median & Range & Median & Range & Median & Range & Median & Range \\
\hline Milk reception & 860 & $770-950$ & 14639 & $2658-26620$ & 290 & $190-390$ & 480 & $430-530$ \\
\hline Milk storage & 680 & $380-980$ & 2345 & $2190-2500$ & 265 & $190-340$ & 330 & $320-340$ \\
\hline Cheese production & 120 & $110-130$ & 1940 & $1690-2190$ & 50 & $30-70$ & 95 & $90-100$ \\
\hline Packaging area & 265 & $180-350$ & 265 & $200-330$ & 70 & $40-100$ & 55 & $20-90$ \\
\hline
\end{tabular}

For the most frequently isolated species and for the microbial agents belonging to the risk group 2, identified using biochemical and microscopic techniques, the molecular analysis confirmed their sequence similarities at the level of 99-100\%, with the sequences deposited in the GenBank database.

Quantitative analysis of surface samples. Concentrations of bacteria and fungi on surfaces in CD as well as TD ranged between 1.0-49.7 CFU/ $/ \mathrm{cm}^{2}$ and $0.2-60.4 \mathrm{CFU} / \mathrm{cm}^{2}$, as well as between $0-2.7 \mathrm{CFU} / \mathrm{cm}^{2}$ and $0-4.6 \mathrm{CFU} / \mathrm{cm}^{2}$, respectively (Tab. 5). The highest concentrations of bacteria in CD and TD were observed on cheese production worktops $\left(49.7 \mathrm{CFU} / \mathrm{cm}^{2}\right.$ and $60.4 \mathrm{CFU} / \mathrm{cm}^{2}$, respectively), followed by worktops in milk reception and surfaces of tanks in milk storage. The highest concentrations of fungi in CD were observed on worktops in the cheese production area $\left(2.7 \mathrm{CFU} / \mathrm{cm}^{2}\right)$, while in TD on worktops in milk reception $\left(4.6 \mathrm{CFU} / \mathrm{cm}^{2}\right)$. There were no fungi detected on worktops in the cream and butter production area, or on surfaces from conveyor belts in packaging area in both CD and TD.
Qualitative analysis of surface samples. Percentage distribution of microbial groups identified on surfaces in the studied dairies is shown in Figure 1. On surfaces in both $\mathrm{CD}$ and TD, non-sporing Gram-positive rods (including LABs), as well as Gram-positive cocci, were predominant constituting $60.8 \%$ and $57.5 \%$, as well as $30.4 \%$ and $28.3 \%$ of total microbiota, respectively. All bacterial and fungal species isolated from surfaces as well as their percentage contribution to the total microbiota are listed in Table 4 . In the case of bacteria, 16 species belonging to 9 genera were isolated from surfaces at workplaces in CD, while 18 species belonging to 10 genera were isolated at workplaces in TD. The most frequently isolated bacterial strains in CD were Lactobacillus delbruecki ssp. delbruecki (20.5\%), followed by Bifidobacterium spp. (17.1\%), and Lactobacillus fermentum (13.2\%). The most frequently isolated bacterial strains from surfaces in TD were Lactobacillus curvatus (18.5\%), followed by Lactobacillus paracasei ssp. paracasei (14.3\%), Streptococcus thermophilus (10.5\%), and Lactobacillus fermentum (11.2\%). In turn, 11 fungal species belonging to 9 genera were isolated from surfaces in $\mathrm{CD}$, while 13 species belonging to 9 genera were
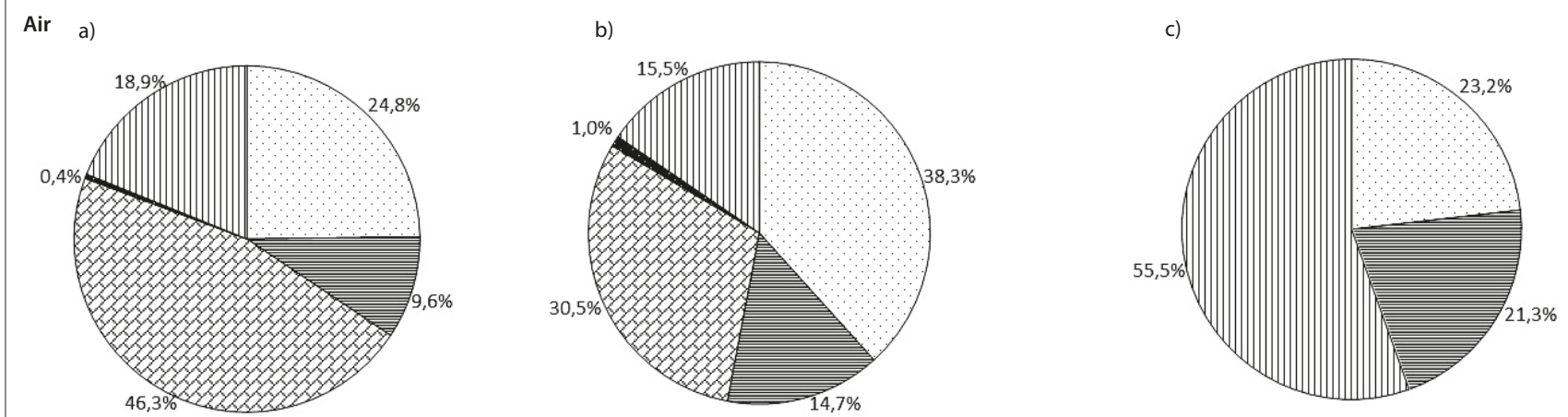

Surfaces
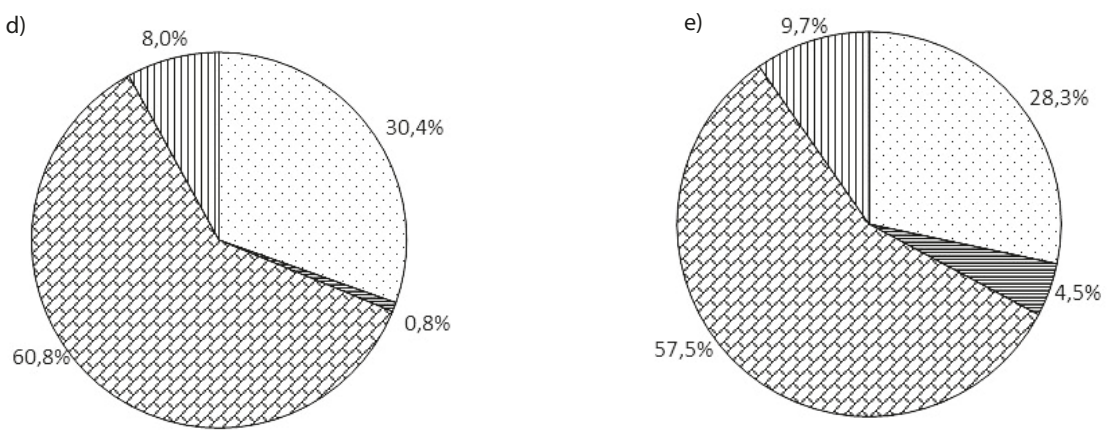

Gram-positive cocci

Gram-positive bacilli,

Q non-sporing Gram-positive,

$\because$ mesophilic actinomycetes

Figure 1. Percentage contribution of microbial groups to total microbiota isolated from the air $(a-c)$ and surfaces (d-e) samples collected in commercial $(C D$ : a, d) and traditional (TD: b, e) dairies as well as in atmospheric air (c) 
Table 4. Percentage contribution (\%) of bacteria and fungi to total microbiota isolated from the air and surface samples collected in commercial (CD) and traditional (TD) dairies as well as in atmospheric (background) air

Sample origin

Microbial group/genus/species

\begin{tabular}{cccc}
\multicolumn{4}{c}{ Sample origin } \\
\hline \multicolumn{3}{c}{ CD } & \multicolumn{3}{c}{ TD } \\
\hline \multirow{2}{*}{ Air } & Surface & Air & Surface
\end{tabular}

Atmospheric

background

\begin{tabular}{|c|c|c|c|c|c|c|c|}
\hline \multirow{39}{*}{ 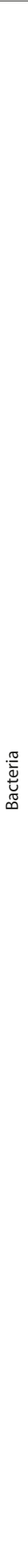 } & \multirow{19}{*}{$\begin{array}{l}\text { Gram-positive } \\
\text { cocci }\end{array}$} & Aerococcus spp. & $\mathrm{nd}^{\mathrm{a})}$ & nd & 0.5 & nd & nd \\
\hline & & Kocuria kristinae & 1.2 & nd & nd & nd & nd \\
\hline & & Kocuria rosea & nd & nd & nd & nd & 6.3 \\
\hline & & Kocuria spp. & nd & 0.5 & nd & nd & nd \\
\hline & & Lactococcus lactis ssp. lactis $^{G}$ & 4.2 & nd & 4.4 & 4.0 & nd \\
\hline & & Leuconostoc mesenteroides ssp. cremoris ${ }^{G}$ & nd & 5.0 & nd & 2.0 & nd \\
\hline & & Micrococcus luteus & nd & nd & 2.7 & nd & nd \\
\hline & & Micrococcus spp. & 8.4 & 1.5 & 3.0 & 0.5 & 13.6 \\
\hline & & Staphylococcus aureus * & nd & 2.7 & 4.5 & 5.1 & nd \\
\hline & & Staphylococcus caprae & nd & nd & 1.6 & nd & nd \\
\hline & & Staphylococcus capitis & nd & 1.4 & nd & nd & nd \\
\hline & & Staphylococcus haemolyticus & 1.3 & 1.6 & nd & nd & nd \\
\hline & & Staphylococcus saccharolyticus & nd & nd & 3.5 & nd & nd \\
\hline & & Staphylococcus sciuri & nd & 1.0 & nd & 1.0 & nd \\
\hline & & Staphylococcus simulans & 0.5 & nd & 0.5 & nd & 0.6 \\
\hline & & Staphylococcus spp. & 1.5 & nd & 0.5 & nd & 2.0 \\
\hline & & Staphylococcus xylosus & 1.0 & 1.8 & 0.5 & 1.0 & 0.7 \\
\hline & & Streptococcus intermedius * & nd & 7.0 & 4.1 & 4.2 & nd \\
\hline & & Streptococcus thermophilus ${ }^{G}$ & 6.7 & 7.9 & 11.5 & 10.5 & nd \\
\hline & \multirow{6}{*}{$\begin{array}{l}\text { Gram-positive } \\
\text { bacilli }\end{array}$} & Bacillus cereus & 4.5 & nd & 6.9 & 2.2 & 2.0 \\
\hline & & Bacillus circulans & nd & nd & 1.7 & nd & nd \\
\hline & & Bacillus mycoides & nd & nd & 0.5 & nd & nd \\
\hline & & Bacillus pumilus & 1.5 & nd & 0.5 & nd & 3.5 \\
\hline & & Bacillus spp. & 2.6 & nd & 1.2 & nd & 15.8 \\
\hline & & Clostridium perfringens* & nd & 0.8 & nd & 1.9 & nd \\
\hline & \multirow{12}{*}{$\begin{array}{l}\text { Non-sporing } \\
\text { Gram-positive } \\
\text { rods }\end{array}$} & Bifidobacterium spp. ${ }^{G}$ & 17.8 & 17.1 & 15.6 & 5.0 & nd \\
\hline & & Lactobacillus buchneri ${ }^{G}$ & nd & nd & nd & 2.5 & nd \\
\hline & & 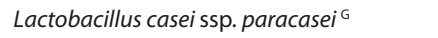 & nd & nd & nd & nd & nd \\
\hline & & Lactobacillus curvatus ${ }^{G}$ & nd & nd & 3.5 & 18.5 & nd \\
\hline & & Lactobacillus delbrueckii ssp. delbrueckii ${ }^{\mathrm{G}}$ & 3.4 & 20.5 & nd & 5.5 & nd \\
\hline & & Lactobacillus fermentum $^{G}$ & nd & 13.2 & nd & 11.2 & nd \\
\hline & & Lactobacillus lactis ssp. cremoris ${ }^{G}$ & nd & nd & 5.0 & nd & nd \\
\hline & & Lactobacillus lactis ssp. lactis ${ }^{G}$ & 6.9 & nd & 4.7 & nd & nd \\
\hline & & Lactobacillus plantarum $^{G}$ & nd & nd & 0.5 & nd & nd \\
\hline & & Lactobacillus paracasei ssp. paracasei ${ }^{G}$ & 9.7 & 9.0 & nd & 14.3 & nd \\
\hline & & Lactobacillus spp. ${ }^{G}$ & 8.5 & nd & 1.2 & nd & nd \\
\hline & & Microbacterium spp. & nd & 1.0 & nd & 0.5 & nd \\
\hline & \multirow{2}{*}{ Ma } & Actinomyces spp.* & 0.4 & nd & nd & nd & nd \\
\hline & & Streptomyces spp.* & nd & nd & 1.0 & nd & nd \\
\hline
\end{tabular}


Table 4. Percentage contribution (\%) of bacteria and fungi to total microbiota isolated from the air and surface samples collected in commercial (CD) and traditional (TD) dairies as well as in atmospheric (background) air (Continuation)

Microbial group/genus/species

\begin{tabular}{ccccc}
\multicolumn{5}{c}{ Sample origin } \\
\hline \multicolumn{3}{c}{ CD } & \multicolumn{3}{c}{ TD } & $\begin{array}{c}\text { Atmospheric } \\
\text { background }\end{array}$ \\
\hline \multirow{2}{*}{ Air } & Surface & Air & Surface &
\end{tabular}

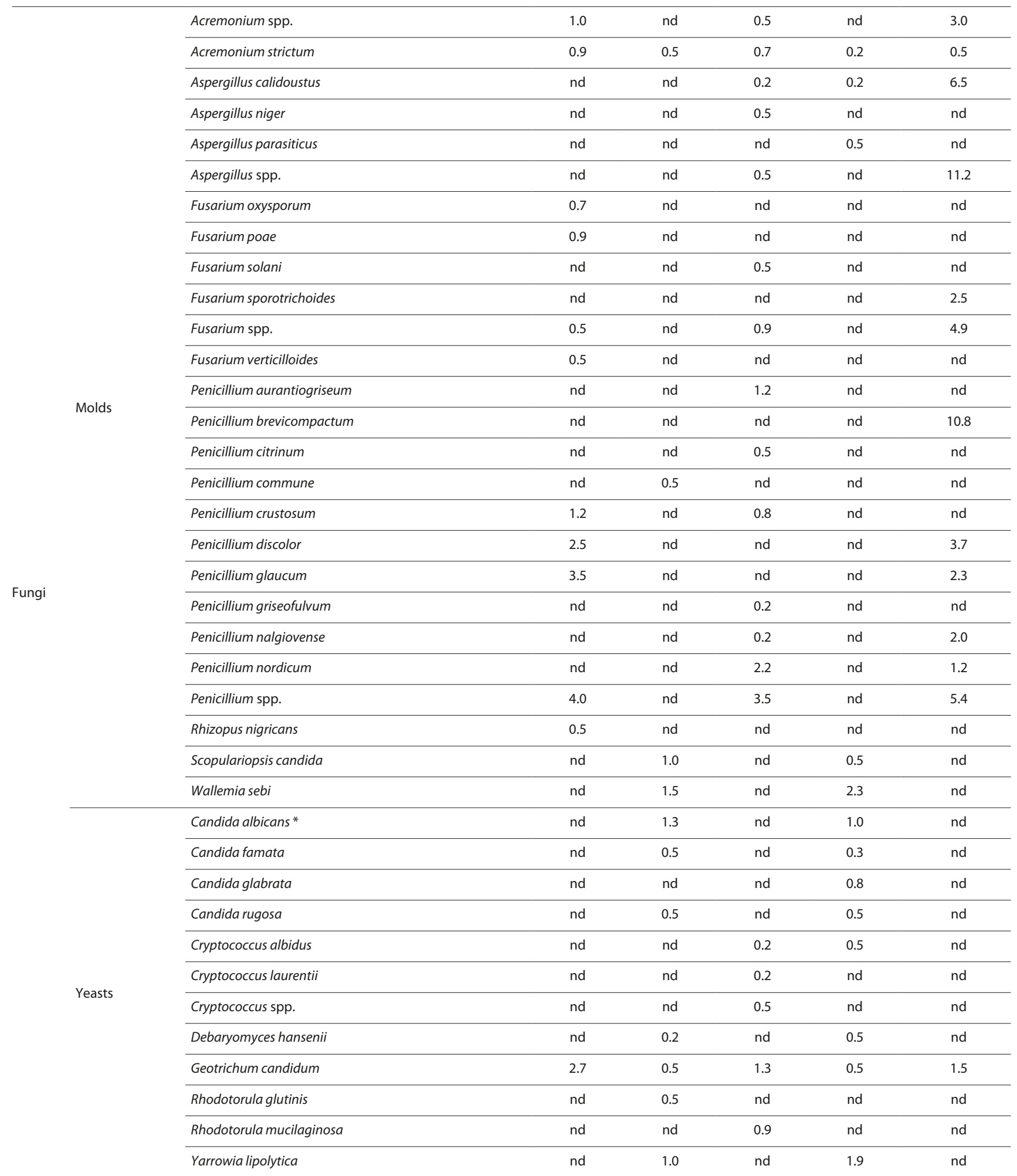

a) nd - not detected; Ma - mesophilic actinomycetes; ${ }^{6}$ - species with GRAS status; ${ }^{*}$ - biological agents from risk group 2 (according to the classifications in Directive $2000 / 54 / E C$ and in Ordinance of the Polish Minister of Health). 
Table 5. Concentrations of bacteria and fungi $\left(\mathrm{CFU} / \mathrm{cm}^{2}\right)$ on surfaces in commercial (CD) and traditional (TD) dairies

\begin{tabular}{|c|c|c|c|c|c|c|c|c|}
\hline \multirow{3}{*}{ Type of surface } & \multicolumn{4}{|c|}{ Bacteria } & \multicolumn{4}{|c|}{ Fungi } \\
\hline & \multicolumn{2}{|c|}{$C D$} & \multicolumn{2}{|c|}{ TD } & \multicolumn{2}{|c|}{$C D$} & \multicolumn{2}{|c|}{ TD } \\
\hline & Median & Range & Median & Range & Median & Range & Median & Range \\
\hline Worktops in milk reception & 21.8 & $19.3-27.4$ & 50.1 & $49.8-50.3$ & 1.2 & $0.9-1.4$ & 4.6 & $4.2-4.7$ \\
\hline Surfaces of tanks in milk storage & 22.7 & $21.9-23.2$ & 40.1 & $39.8-42.5$ & 0.5 & $0.1-1.0$ & 2.0 & $0.9-4.0$ \\
\hline Worktops in cheese production & 49.7 & $43.2-58.2$ & 60.4 & $55.1-67.1$ & 2.7 & $1.6-3.0$ & 2.2 & $1.5-2.6$ \\
\hline Conveyor belts in packaging area & 1.0 & $0.4-1.2$ & 0.7 & $0.2-1.0$ & 0 & $0-0$ & 0 & $0-0$ \\
\hline
\end{tabular}

Table 6. Microbial pathogens isolated from the air and surfaces in commercial (CD) and traditional (TD) dairies

\begin{tabular}{|c|c|c|c|c|}
\hline \multirow{2}{*}{ Microorganism } & \multicolumn{2}{|r|}{$C D$} & \multicolumn{2}{|c|}{ TD } \\
\hline & Bioaerosol & Surface & Bioaerosol & Surface \\
\hline Staphylococcus aureus & $n d^{a)}$ & Worktops in milk reception & $\begin{array}{c}\text { Milk reception } \\
\text { Cheese production } \\
\text { Cream and butter production }\end{array}$ & $\begin{array}{c}\text { Worktops in milk reception } \\
\text { Worktops in cheese production } \\
\text { Worktops in cream and butter production }\end{array}$ \\
\hline Streptococcus intermedius & nd & Worktops in milk reception & Cheese production & $\begin{array}{c}\text { Worktops in milk reception } \\
\text { Worktops in cheese production } \\
\text { Worktops in cream and butter production }\end{array}$ \\
\hline Clostridium perfringens & nd & Worktops in milk reception & nd & Worktops in milk reception \\
\hline Streptomyces spp. & nd & nd & Milk reception & nd \\
\hline Actinomyces spp. & Milk reception & nd & nd & nd \\
\hline Candida albicans & nd & $\begin{array}{l}\text { Worktops in milk reception } \\
\text { Tanks surfaces in milk storage }\end{array}$ & Cheese production & $\begin{array}{l}\text { Worktops in milk reception } \\
\text { Surfaces of tanks in milk storage } \\
\text { Worktops in cheese production }\end{array}$ \\
\hline
\end{tabular}

a) nd - not detected

isolated from surfaces in TD. The comparison between dairies revealed that the studied surfaces were, to the same extent, contaminated with moulds and yeasts.

As in the case of air samples, biological agents from risk group 2 were also detected on the tested surfaces. In CD, Staphylococcus aureus constituted 2.7\%, Streptococcus intermedius $7.0 \%$, Clostridium perfringens $0.8 \%$, and Candida albicans $1.3 \%$ of total surface microbiota. In TD, the contribution of Staphylococcus aureus, Streptococcus intermedius, Clostridium perfringens, and Candida albicans to total surface microbiota, was equal $5.1 \%, 4.2 \%, 1.9 \%$, and $1.0 \%$, respectively. Also for these microorganisms, molecular analysis positively verified their sequence similarities at the level of $99-100 \%$, with the sequences deposited in the GenBank database.

Bacterial and fungal pathogens in dairies. Strains belonging to the group 2 according to Directive 2000/54/EC and Ordinance of the Minister of Health and the workplaces where they were detected are listed in Table 6. Staphylococcus aureus, S. intermedius, Streptomyces spp., and C. albicans were isolated from bioaerosols samples collected in TD, while Actinomyces spp. was present in bioaerosol samples collected in CD. All these strains were primarily detected within milk reception zones (CD, TD), cheese production (TD), and cream and butter production (TD) areas. Staphylococcus aureus, $S$. intermedius, C. perfringens, and C. albicans contaminated surfaces in both CD and TD, and were isolated from worktops in milk reception, tanks surfaces in milk storage, worktops in cheese as well as in cream and butter production areas.

\section{DISCUSSION}

This study confirmed that bacteria and fungi are commonly present at workplaces in dairies. The higher concentrations of bacteria and fungi in the air and on surfaces were obtained in TD compared to CD. Regardless the level of automation of dairy production in $\mathrm{CD}$ and $\mathrm{TD}$, the most microbiologically polluted workplaces were located within milk reception and milk storage areas. Poor microbial quality in small scale dairies with manual processing has also been observed by other authors [37]. Air quality studies conducted by Salustiano et al. [38] revealed that the highest bacterial concentrations were observed in milk reception $\left(313 \mathrm{CFU} / \mathrm{m}^{3}\right)$ and cheese production areas $\left(381 \mathrm{CFU} / \mathrm{m}^{3}\right)$, while the highest concentrations of fungi were found in butter and cream $\left(410 \mathrm{CFU} / \mathrm{m}^{3}\right)$ and cheese production sections (342 CFU/m ${ }^{3}$ ). According to Belestioids et al. [39], the concentration of fungal aerosol in the yoghurt production area was on the level of $70 \mathrm{CFU} / \mathrm{m}^{3}$. Against this background, the results regarding bacteria concentration in the air of milk reception area obtained in the current study were higher (in $\mathrm{CD}$ equal to $860 \mathrm{CFU} / \mathrm{m}^{3}$; in TD equal to $14639 \mathrm{CFU} / \mathrm{m}^{3}$ ) than those observed by Salustiano et al. [38]; however, the results regarding bacterial and fungal concentrations in the air at workplaces of other studied dairy sections were lower.

Generally, higher concentrations of microorganisms in the air in this study, with statistically significant differences in case of bacteria, were observed in traditional dairies than in commercial ones. It is known that environmental factors may affect bioaerosols concentration and diversity [40], thus there are several factors that may contribute to air pollution in these dairy processing areas. Among them, the processed material (especially raw milk), manufacturing 
practices and microclimate parameters play an essential role in determining the concentration of microorganisms [41]. For example, Salustiano et al. [38] noticed that air humidity affects the fungal concentration in bioaerosols; however, in the current study neither humidity nor temperature significantly influenced the airborne bacterial and fungal concentrations ( $p>0.05)$. High concentrations of bacteria and fungi in the air of the milk reception and milk storage areas observed in this study may result from the high intensity movement of a large number of milk suppliers, local farmers, and dairy workers. Moreover, the frequently performed cleaning of milk tanks using pressurized water may also led to aerosolization of raw milk residues along with microorganisms growing on them. As described in the Guide to Environmental Microbiological Testing for the Food Industry [42], most food manufacturing processes involve one or more steps that effectively kill pathogenic bacteria; however, the manufacturing of some dairy products may not involve such steps in the production cycle. Thus, dairy workers may be exposed to microbiological agents throughout all production process.

Despite the fact that a few hundred million workers around the world are exposed to airborne biological agents, there are still no widely accepted threshold limit values for microbial contaminants. Among the reasons for this are: difficulties in determination of the dose-response relationship for most biological agents, inability to identify individual microbial species responsible for adverse health outcomes, individual susceptibility to a specific biological agent of exposed person, a lack of standardization of sampling methods and experimental procedures, and a still insufficient database regarding environmental and occupational concentrations of biological agents. Being aware of all these scarcities, the Polish Expert Group for Biological Agents of the Interdepartmental Commission for Maximum Admissible Concentrations and Intensities for Agents Harmful to Health in the Working Environment at the Central Institute for Labour ProtectionNational Research Institute (CIOP-PIB), proposed threshold limit values (TLV) for microbiological agents in the air of occupational and non-occupational environments, taking 'environmental factors' into account (Tab. 7) [43, 44, 45]. Several other authors also proposed air quality standards dedicated to different dairy processing areas (Tab. 8) [46, 47].

Based on the above, from the workers' safety point of view in both $\mathrm{CD}$ and TD in the current study, the threshold limit values for microbiological agents in the air were not

Table 7. Threshold limit values for bioaerosols proposed by the Polish Expert Group for Biological Agents of the Interdepartmental Commission for Maximum Admissible Concentrations and Intensities for Agents Harmful to Health in the Working Environment (Górny et al., 2008; Górny et al., 2007; Pośniak, 2018)

\begin{tabular}{lcc}
\hline Microbial agent & $\begin{array}{c}\text { Workplaces } \\
\text { polluted with } \\
\text { organic dust }\end{array}$ & $\begin{array}{c}\text { Residential and } \\
\text { public utility } \\
\text { premises }\end{array}$ \\
\hline Mesophilic bacteria & $100,000 \mathrm{CFU} / \mathrm{m}^{3}$ & $5,000 \mathrm{CFU} / \mathrm{m}^{3}$ \\
\hline Gram-negative bacteria & $20,000 \mathrm{CFU} / \mathrm{m}^{3}$ & $200 \mathrm{CFU} / \mathrm{m}^{3}$ \\
\hline Thermophilic actinomycetes & $20,000 \mathrm{CFU} / \mathrm{m}^{3}$ & $200 \mathrm{CFU} / \mathrm{m}^{3}$ \\
\hline Fungi & $50,000 \mathrm{CFU} / \mathrm{m}^{3}$ & $5,000 \mathrm{CFU} / \mathrm{m}^{3}$ \\
\hline Microbial agents from risk groups 3 and 4 & $0 \mathrm{CFU} / \mathrm{m}^{3}$ & $0 \mathrm{CFU} / \mathrm{m}^{3}$ \\
\hline Bacterial endotoxins & $200 \mathrm{ng} / \mathrm{m}^{3}$ & $5 \mathrm{ng} / \mathrm{m}^{3}$ \\
& $\left.(2,000 \mathrm{EU}) / \mathrm{m}^{3}\right)$ & $\left(50 \mathrm{EU} / \mathrm{m}^{3}\right)$ \\
\hline
\end{tabular}

a) CFU - colony forming unit; ${ }^{b} \mathrm{EU}$ - endotoxin unit
Table 8. Suggested air quality standards for various processing areas in dairy industry (Mostert and Jooste, 2002; Luck and Gavron, 1990)

\begin{tabular}{lcccc}
\hline \multirow{2}{*}{ Processing area } & \multicolumn{2}{c}{ Bacteria } & \multicolumn{2}{c}{ Yeasts and molds } \\
\cline { 2 - 5 } & Satisfactory & Unsatisfactory & Satisfactory & Unsatisfactory \\
\hline $\begin{array}{l}\text { Fermented } \\
\text { milk products, } \\
\text { cottage cheese }\end{array}$ & $<150 \mathrm{CFU} / \mathrm{m}^{3}$ & $>1500 \mathrm{CFU} / \mathrm{m}^{3}$ & $<50 \mathrm{CFU} / \mathrm{m}^{3}$ & $>1000 \mathrm{CFU} / \mathrm{m}^{3}$ \\
\hline Milk and cream & $<150 \mathrm{CFU} / \mathrm{m}^{3}$ & $>1500 \mathrm{CFU} / \mathrm{m}^{3}$ & $<50 \mathrm{CFU} / \mathrm{m}^{3}$ & $>1000 \mathrm{CFU} / \mathrm{m}^{3}$ \\
\hline Butter & $<100 \mathrm{CFU} / \mathrm{m}^{3}$ & $>1000 \mathrm{CFU} / \mathrm{m}^{3}$ & $<50 \mathrm{CFU} / \mathrm{m}^{3}$ & $>1000 \mathrm{CFU} / \mathrm{m}^{3}$ \\
\hline Powdered milk & $<200 \mathrm{CFU} / \mathrm{m}^{3}$ & $>2000 \mathrm{CFU} / \mathrm{m}^{3}$ & $<100 \mathrm{CFU} / \mathrm{m}^{3}$ & $>1000 \mathrm{CFU} / \mathrm{m}^{3}$ \\
\hline $\begin{array}{l}\text { Ripened } \\
\text { cheese }\end{array}$ & $<200 \mathrm{CFU} / \mathrm{m}^{3}$ & $>2000 \mathrm{CFU} / \mathrm{m}^{3}$ & $<100 \mathrm{CFU} / \mathrm{m}^{3}$ & $>1000 \mathrm{CFU} / \mathrm{m}^{3}$
\end{tabular}

${ }^{a} \mathrm{CFU}$ - colony forming unit

exceeded. However, taking into account the suggested hygienic standards for the dairy industry, the obtained results were not satisfactory. The concentrations of bacteria in the air at almost all workplaces in TD (excluding the packaging area) and within the milk reception and milk storage areas in CD were above the proposed TLVs. The concentrations of fungi at all workplaces in both types of studied diaries were also not satisfactory. Airborne fungi may be responsible for dairy product contamination and their spoilage, and (even in low concentrations) can cause many adverse health effects, including respiratory disorders, e.g. allergic diseases, bronchial asthma, and allergic pulmonary alveolitis, as well as skin allergies or irritations [48].

Raw milk may also contaminate processing area surfaces and, as such, become a secondary emission source for the bioaerosols [38]. Moreover, the attachment of microorganisms to surfaces and processing equipment may lead to biofilm formation which can affect the safety and quality of food products [49]. In the studied dairies, the most bacterially contaminated surfaces were worktops in cheese production and milk reception areas, as well as the surface of tanks in milk storage. In the case of fungi, the most contaminated surfaces in CD were the worktops in cheese production, while in TD the worktops in milk reception.

There are several proposals regarding the cleanliness of surfaces in the dairy industry. According to Godlewska [50], permissible contamination for dairy equipment surfaces should not exceed $100 \mathrm{CFU} / \mathrm{cm}^{2}$. Other sources indicate that for cleaned contact surfaces, the satisfactory level of total viable microorganisms should be less than $80 \mathrm{CFU} / \mathrm{cm}^{2}[37,51]$. Taking into account standards indicated by the Public Health Laboratory Service [51], the levels of contamination of tested surfaces were not exceeded. Nevertheless, dermal contact with some microorganisms, e.g. LABs and strains belonging to the risk group 2, according to Directive 2000/54/EC may play an important role in skin irritation and other adverse health outcomes among exposed workers. It should also be emphasized that according to microbiological guidelines, $S$. aureus belonging to the risk group 2 according to Directive $2000 / 54 / E C$, detected in the current study on worktops in milk reception (CD, TD), worktops in cheese production (TD) and worktops in cream and butter production areas (TD), should be absent on all food-contact surfaces $[37,52]$.

In this study, a total of 43 microbial species belonging to 14 genera were isolated from the dairies. Gram-positive cocci and non-sporing Gram-positive rods were the predominant groups, both in bioaerosol and on surfaces in CD and TD. Higher concentrations of bacteria and fungi were mainly 
observed in TD, where manual processing of raw milk was the method of its technological handling. Gram-positive cocci, isolated in this study, are usually a part of the human and animal microbiota, but may also be common in the environment. The species from Staphylococcus, Streptococcus, Leuconostoc, and Lactococcus genera are especially, characteristic for the working environment where raw milk is usually processed [53]. Two pathogens from this group, Staphylococcus aureus and Streptococcus intermedius, present in bioaerosols from TD and on surfaces form CD and TD may cause skin, subcutaneous, soft tissue and systemic infections, as well as inflammation of the lungs, endocarditis, and necrotizing fasciitis $[54,55,56]$. Both these strain, probably originated from the processed milk, are responsible for mastitis in cattle and are often present in raw milk $[57,58]$. Staphylococcus aureus has also been frequently isolated from cheese production lines [59]. According to Schlegelová et al. [60] staphylococci are present quite often in dairies on technical equipment, and the results obtained in the current study confirmed this observation. This study also indicates the fact that contamination of food contact surfaces was relatively high even after their sanitation process. It is worth mentioning that the equipment surfaces in dairy facilities may be contaminated with staphylococci closely related to multi-resistant strains persisting in biofilm communitie, and this information should be kept in mind when efficient hygienic procedures have to be introduced into the production processes $[37,52]$.

In turn, non-sporing Gram-positive rods belonging to the Bifidobacterium and Lactobacillus genera are probiotic bacteria, also known as lactic acid bacteria. They are desirable in the dairy production processes and their occurrence is a natural phenomenon in this environment $[61,62]$. Many of the identified LABs have GRAS status [20,63]; however, according to Zeilfelder et al. [21], they may cause irritations and generate specific immune responses among exposed workers. Hence, their presence in the occupational environment should be always taken into account during risk exposure assessment.

Other Gram-positive bacteria, including the Bacillus species, as well as mesophilic actinomycetes (like those from Streptomyces and Actinomyces genera), are commonly present in the environment, mainly in soil and plants. They are probably transmitted to the workplaces with outdoor air through the ventilation system and/or by humans on their cloths and footwear [41]. However, some other isolated species from this group, e.g. anaerobic Clostridium perfringens and aerobic Bacillus cereus, may come from processed milk and have been already detected in milk tanks $[64,65,66]$. Bacterial strains belonging to Bacillus, Leuconostoc, Kocuria, and Staphylococcus genera have been also isolated in dairy plants by other authors and seem to be typical for microbiota of these types of processing areas [67].

Regarding the mycobiota of the studied dairies, the identified moulds represent typical environmental species and in the observed concentrations should not pose a risk to workers with a properly functioning immune system. In dairies, mould contaminants are derived mainly from the atmospheric air, while yeasts usually originate from milk. Regardless of animal species, raw milk generally may contain fungi (usually more yeast cells than fungal conidia) in concentrations between $10^{3}-10^{5} \mathrm{CFU} / \mathrm{mL}$ [68]. Candida albicans shows a high prevalence in milk from cows in
Poland. In term of yeasts, however, some pathogenic strains were present both in the air and on surfaces from studied dairies. Candida albicans and other Candida species are by far the most common causes of bovine mastitis [69]. $C$. albicans is also a major fungal pathogen for humans that may cause mucosal infections and, in certain groups of vulnerable individuals, severe, life-threatening bloodstream infections and subsequent infections of the internal organs [70]. Strains belonging to species Cryptococcus, Geotrichum, Rhodotorula, Debaryomyces, and Yarrowia occur in milk and dairy products as non-starter yeasts. They may make important contributions to the flavour and texture of specialty cheeses [10]; however, the health impact of most of the non-starter yeasts and moulds remains unknown.

An important part of safety work management is proper health risk assessment. Identification and classification of isolated microorganisms to a proper risk group, depending on the ability of microorganism to causing infection, the possibility of spreading and prophylaxis methods and effective treatment, should be taken into account in the initial stage of occupational risk assessment. It should be noted that in case of harmful biological agents, occupational activities with bioaerosols production (e.g. cleaning milk tanks), work with high concentrations of substances (e.g. adding starter cultures) or manual activities with the risk of injury, may increase the level of infection risk for workers.

\section{CONCLUSIONS}

Bioaerosols and surfaces in the occupational environment in dairies contain a high diversity of microorganisms, regardless of the type of dairy plant. This study revealed that, compared to commercial dairies, a higher bacterial and fungal contamination of the processing environment was observed in traditional dairie, where the manual processing of raw milk was the method of its technological handling. In both $\mathrm{TD}$ and $\mathrm{CD}$, the noted microbial air and surface concentrations did not exceed the threshold limit values proposals; however, from the point of view of microbial quality of processing areas, the measured contamination levels were not satisfactory in most cases. What is important, is that the strains belonging to risk group 2 according to Directive 2000/54/EC were present in bioaerosol and surface samples in both types of studied dairies and, as such, may significantly influence the health status of dairy workers and the quality of milk products. Thus, the control of microbial air and surface contamination should be routinely carried out as a part of hygienic quality assessment within dairies. Moreover, identification and classification of isolated microorganisms toa proper risk group should be an essential part of occupational risk assessment. The introduction and improvement of adequate hygienic practices, such as hand washing and cleaning and disinfection procedures, should directly enhance the microbial quality of the processing environment, and translate into the improvement of safety of both dairy workers and consumers.

\section{Conflict of interest}

The authors declare that they have no conflict of interest. 


\section{Acknowledgements}

This study was based on the results of a research project undertaken within the scope of the IV stage of the National Programme 'Improvement of safety and working conditions', partly supported in 2017-2019, within the scope of research and development, by the Ministry of Science and Higher Education/National Centre for Research and Development, with the Central Institute for Labour Protection/National Research Institute as main co-ordinator of the programme (Project No. II.N.16).

The authors express their thanks all employees of the dairy farms who assisted in the performance and completion of this study.

\section{REFERENCES}

1. IDF - International Dairy Federation. The Economic Importance of Dairying IDF Factsheet. 2013; https://www.fil-idf.org/wp-content/ uploads/2016/04/The-economic-importance-of-dairying.pdf

2. Holah JT. Industrial Monitoring: Hygiene in Food Processing. In: Melo LF, Bott TR, Fletcher M, Capdeville B, editors. Biofilms - Science and Technology. NATO ASI Series (Series E: Applied Sciences). vol. 223, Dordrecht: Springer; 1992, p. 645-659.

3. Duszkiewicz-Reinhard W, Grzybowski R, Sobczak E. Theory and practice in food microbiology, Warsaw, Poland: University of Life Sciences, 2003.

4. Dhanashekar R, Akkinepalli S, Nellutla A. Milk-borne infections. An analysis of their potential effect on the milk industry. GERMS. 2012; 2(3): 101-109.

5. Fugl A, Berhe T, Kiran A, Hussain S, Laursen MF, Bahl MI, Hailu Y, Sørensen KI, Guya ME, Ipsen R, Hansen EB. Characterisation of lactic acid bacteria in spontaneously fermented camel milk and selection of strains for fermentation of camel milk. Int Dairy J. 2017; 73: 19-24.

6. Khedid K, Faid Lex M, Mokhtari A, Soulaymani A, Zinedine A. Characterization of lactic acid bacteria isolated from the one humped camel milk produced in Morocco. Microbiol Res. 2009; 164(1): 81-91.

7. Oliver SP, Jayarao BM, Almeida RA. Foodborne pathogens in milk and the dairy farm environment: Food Safety and Public Health Implications. Foodborne Path Dis. 2005; 2(2): 115-129.

8. Barros LS, Sóglia SLO, Rodrigues MJ, Branco MPC. Aerobic and anaerobic bacteria and Candida species in crude milk. J Microbiol Antimicrobials. 2011; 3(8): 206-212.

9. Delavenne E, Mounier J, Asmani K, Jany JL, Barbier G, Le Blay G. Fungal diversity in cow, goat and ewe milk. Int J Food Microbiol. 2011; 151(2): 247-51.

10. Lavoie K, Touchette M, St-Gelais D, Labrie S. Characterization of the fungal microflora in raw milk and specialty cheeses of the province of Quebec. Dairy Sci Tech. 2012; 92(5): 455-68.

11. FDA US Food and Drug Administration (FDA). Department of Health and Human Services, Office of Food additive safety, Available at: https://www.accessdata.fda.gov/scripts/ $\mathrm{fdcc} /$ ?set=GRASNotices\&sort=GRN_No\&order=DESC\&startrow $=1$ \&type=basic\&search=Lactobacillus https://www.accessdata.fda.gov/ scripts/fdcc/?set=GRASNotices\&sort=GRN_No\&order=DESC\&start row=1\&type=basic \&search=bifidobacterium https://www.accessdata fda.gov/scripts/fdcc/?set=GRASNotices\&sort=GRN_No\&order=DES C\&startrow $=1 \&$ type $=$ basic\&search $=$ streptococcus

12. Centers for Disease Control and Prevention (CDC). Healthy living - raw (unpasteurized) milk. 2018; https://www.cdc.gov/features/rawmilk/ index.html

13. Murphy SC, Martin NH, Barbano DM, Wiedmann M. Influence of raw milk quality on processed dairy products: How do raw milk quality test results relate to product quality and yield? J Dairy Sci. 2016; 99(12): 10128-10149.

14. Gücükoğlu A, Kevenk TO, Uyanik T, Cadirci O, Terzi G, Alişarli M. Detection of enterotoxigenic Staphylococcus aureus in raw milk and dairy products by multiplex PCR. J Food Sci. 2012; 77(11): 620-623.

15. Montel MC, Buchin S, Mallet A, Delbes-Paus C, Vuitton DA, Desmasures N, Berthier F. Traditional cheeses: rich and diverse microbiota with associated benefits. Int J Food Microbiol. 2014; 177: 136-154.

16. Kongo JM. Lactic acid bacteria as starter-cultures for cheese processing: past, present and future developments, lactic acid bacteria. R \& D for
Food, Health and Livestock Purposes. InTech., 2013; doi: https://doi. org/10.5772/55937.

17. Leroy F, De Vuyst L. Lactic acid bacteria as functional starter cultures for the food fermentation industry. Trends Food Sci Tech. 2004; 15(2): 67-78.

18. Simon X, Duquenne P. Assessment of workers' exposure to bioaerosols in a French cheese factory. Ann Occup Hyg. 2014; 58(6): 677-692.

19. Wessels S, Axelsson L, Bech Hansen E, De Vuyst L, Laulund S, Lähteenmäki L, Lindgren S, Mollet B, Salminen S, von Wright A. The lactic acid bacteria, the food chain, and their regulation. Trends in Food Science \& Technology. 2004; 15: 498-505.

20. Dalphin JC, Illig S, Pernet D, Dubiez A, Debieuvre D, Teyssier-Cotte C, Depierre A. Symptoms and respiratory function in a group of Gruyère cheese processors in Comté. Revue des Maladies Respiratoires. 1990; 7(1): 31-37.

21. Zeilfelder B, Chouanière D, Reboux G, Vacheyrou M, Milon A, Wild P, Oppliger A. Health effects of occupational exposure in a dairy food industry, with a specific assessment of exposure to airborne lactic acid bacteria. J Occup Env Med. 2012; 54(8): 969-973.

22. Lange JL, Thorne PS, Kullman GJ. Determinants of culturable bioaerosol concentrations in dairy barns. Ann Agric Environ Med. 1997; 4(2): 187-194.

23. Matković K, Vučemilo M, Vinković B, Pavičić Ž, Tofant A, Matković S. Effect of microclimate on bacterial count and airborne emission from dairy barns on the environment. Ann Agric Environ Med. 2006; 13(2): 349-354.

24. European Committee for Standardization (CEN). Workplace atmosphere-guidelines for measurement of airborne microorganisms and endotoxin (Standard No. EN 13098:2007). Brussels, Belgium: CEN; 2007.

25. Engelhart S, Glasmacher A, Simon A, Exner M. Air sampling of Aspergillus fumigates and other thermotolerant fungi: comparative performance of the Sartorious MD8 airport and the Merck MAS-100 portable bioaerosol sampler. Int J Hyg Environ Health. 2007; 210: 733-739.

26. Lagier LC, Edouard S, Pagnier I, Mediannikov O, Drancourt M, Raoult D. Current and past strategies for bacterial culture in clinical microbiology. Clin Microbiol Rev. 2015; 28(1): 208-236.

27. Klich MA. Identification of common Aspergillus species. Utrecht, The Netherlands: Centraalbureau voor Schimmelcultures, 2002.

28. Owen MK, Ensor DS, Sparks LE. Airborne particle sizes and sources found in indoor air. Atmospheric Env. Part A. General topics. 992; 26: 2149-2162.

29. Samson RA, Hoekstra ES, Frisvad JC. Introduction to food- and airborne fungi. 7 th ed. Utrecht, The Netherlands: Centraalbureau voor Schimmelcultures; 2004.

30. St-Germain G, Summerbell R. Identifying filamentous fungi. Belmont, USA: Star; 1996.

31. Zhang H, You C. A universal PCR method and its application in sequence-based identification of microorganisms in dairy. Int Dairy J. 2018; 85: 41-48.

32. Bosshard PP, Zbinden R, Abels S, Böddinghaus B, Altwegg M, Böttger EC. 16S rRNA gene sequencing versus the API 20 NE System and the VITEK 2 ID-GNB card for identification of nonfermenting Gramnegative bacteria in the clinical laboratory. J Clin Microbiol. 2006; 44(4): 1359-1366.

33. Frank JA, Reich CI, Sharma S, Weisbaum JS, Wilson BA, Olsen GJ. Critical evaluation of two primers commonly used for amplification of bacterial 16S rRNA genes. Appl Environ Microbiol. 2008; 74: 2461-2470.

34. White TJ, Bruns T, Lee S, Tailor S. Amplification and direct sequencing of fungal ribosomal RNA genes for phylogenetics, In: Innins, M.A., Gelf, D.H., Sninsky, J.J., White, T.J., editors. PCR protocols. A guide to methods and applications. USA, San Diego: Academic Press, 1990, p. 315-322.

35. Directive 2000/54/EC of the European Parliament and of the Council of 18 September 2000 on the protection of workers from risks related to exposure to biological agents at work. Official Journal of European Union Lex, 262, 21, 21-45.

36. Ordinance of the Minister of Health of April 22, 2005, on hazardous biological agents in the work environment and the protection of health of workers occupationally exposed to them. J Laws, 81, 716.

37. Opiyo BA, Wangoh J, Njage PKM. Microbiological performance of dairy processing plants is influenced by scale of production and the implemented food safety management system: a case study. J Food Protect. 2013; 70(6): 975-983.

38. Salustiano VC, Andrade NJ, Brandão SCC, Azeredo RMC, Lima SAK. Microbiological air quality of processing areas in a dairy plant as 
evaluated by the sedimentation technique and a one-stage air sampler. Brazilian J Microbiol. 2003; 34: 255-259.

39. Belestioids E, Ghikas D, Kalantzi K. Incorporation of microbiological and molecular methods in HACCP monitoring scheme of moulds and yeasts in a Greek Dairy Plant: A case study -11th International Congress on Engineering and Food (ICEF11). Procedia Food Sci. 2011; 1: 1051-1059.

40. Mbareche H, Veillette M, Bilodeau GJ, Duchaine C. Fungal aerosols at dairy farms using molecular and culture techniques. Sci Total Env. 2019; 653: 253-263.

41. Radha K, Nath LS. Studies on the air quality in a dairy processing plant. Indian J Vet Animal Sci Res. 2014; 43(5): 346-353.

42. Microgen Bioproducts Ltd. A Guide to Environmental Microbiological Testing for the Food Industry (www.microgenbioproducts.com/wpcontent/uploads/sites/8/2016/02/Path-Chek-Guide-to-EnvironmentalMonitoring_09.05.08__9_.pdf)

43. Górny RL, Anczyk E, Dutkiewicz J. The role of standards and limit values for biological agents in protection of workers health-a view from Europe (presentation PS04-57). In: XVIII World Congress on Safety and Health at Work, 2008.

44. Górny RL, Mainelis G, Dutkiewicz J, Anczyk E. Bioaerosols in the environment - should we apply reference values? (Presentation T04016). In: European Aerosol Conference, 2007.

45. Pośniak M. Harmful agents in the working environment-admissible values. Poland, Warsaw: CIOP-PIB, 2018.

46. Mostert JF, Jooste PJ. Quality control inthe dairy industry. In: Robinson RK, editor. Dairy Microbiology Handbook-The Microbiology of Milk and Milk Products. New York: John Wiley and Sons; 2002, p. 655-736.

47. Luck H, Gavron H. Quality control in the dairy industry. In: Robinson RK, editor. Dairy Microbiology-the Microbiology of Milk products. London: Elsevier Applied Science; 1990, p. 345-392.

48. Gołofit-Szymczak M, Górny RL. Microbiological Air Quality in Office Buildings Equipped with Different Ventilation Systems. Indoor Air. 2018; 28: 792-805

49. Fysun O, Kern H, Wilke B, Langowski HC. Evaluation of factors influencing dairy biofilm formation in filling hoses of food-processing equipment. Food Bioprod Process. 2019;113: 39-48.

50. Godlewska K. Hygiene: Quick tests for checking the cleanliness of production areas. Dairy Business Forum. 2015; 1/2015: 20.

51. Herbert M, Donovan T, Manger P. A study of the microbial contamination of working surfaces in a variety of food premises using traditional swabbing technique and commercial contact slides. Public Health Laboratory Service. UK; Ashford, 1990.

52. Dijk R, van den Berg D, Beumer RR, de Boer E, Dijkstra A, Kalkmand $\mathrm{P}$, Stegeman H, Uyttendaele M, Veenedaal H. Microbiologie van Voedingsmiddelen: methoden, principes an criteria (vierdedruk). Uitgeverij Keesing Noordervliet. The Netherlands; Houten, 2007.

53. Gilmour A, Harvey J. Staphylococci in milk and milk products. J Appl Bacteriology. 1990; 69: 147-166.

54. Shinefield HR, Ruff NL. Staphylococcal infections: a historical perspective. Infectious Disease Clinics of North America. 2009; 23(1): $1-15$.
55. Whiley RA, Beighton D, Winstanley TG, Fraser HY, Hardie JM. Streptococcus intermedius, Streptococcus constellatus, and Streptococcus anginosus (the Streptococcus milleri group): association with different body sites and clinical infections. J Clin Microbiol. 1992; 30(1): 243-244.

56. Tong SYC, Davis JS, Eichenberger E, Holland TL, Fowler VG. Staphylococcus aureus infections: epidemiology, pathophysiology, clinical manifestations, and management. Clin Microbiol Rev. 2015; 28(3): 603-661.

57. de Oliveira LP, de Barros LSS, Silva VC, Cirqueira MG. Study of Staphylococcus aureus in raw and pasteurized milk consumed in the Reconcavo area of the State of Bahia. J Food Process Tech. 2011; 2: 6.

58. Nam H, Lim SK, Kang HM, Kim JM, Moon JS, Jang KC, Joo YS, Kang M, Jung SC. Antimicrobial resistance of streptococci isolated from mastitic bovine milk samples in Korea. J Vet Diagn Investig. 2009; 21: 698-701.

59. Alves VF, Niño-Arias FC, Pitondo-Silva A, de Araújo Frazilio D, de Oliveira Gonçalves L, Toubas LC, Sapateiro Torres IM, Oxaran V, Dittmann KK, De Martinis ECP. Molecular characterisation of Staphylococcus aureus from some artisanal Brazilian dairies. Int Dairy J. 2018; 85: 247-253.

60. Schlegelová J, Babák V, Holasová M, Konstantinová L, Necidová L, Šišák F, Vloková H, Roubal P, Jaglic Z. Microbial contamination after sanitation of food contact surfaces in dairy and meat rocessing plants. Czech J Food Sciences. 2010; 20(5): 450-461.

61 . Yerlikaya O. Starter cultures used in probiotic dairy product preparation and popular probiotic dairy drinks. Food Sci Tech. 2014; 34(2): 221-229.

62. Roy D. Technological aspects related to the use of bifidobacteria in dairy products. Lait. 2005; 85: 39-56.

63. Mollet B, Salminen S, von Wright A. The lactic acid bacteria, the food chain, and their regulation. Trends Food Sci Tech. 2004; 15: 498-505.

64. Osama R, Khalifa M, Al-Toukhy M, Al-Ashmawy M. Prevalence and antimicrobial resistance of Clostridium perfringens in milk and dairy products. World J Dairy Food Sci. 2015; 10(2): 141-146.

65. Voidarou C, Bezirtzoglou E, Alexopoulos A, Plessas S, Stefanis C, Papadopoulos I, Vavias S, Stavropoulou E, Fotou K, Tzora A, Skoufos I. Occurrence of Clostridium perfringens from different cultivated soils. Anaerobe. 2011; 17(6): 320-324.

66. Svensson B, Ekelund K, Ogura H, Christiansson A. Characterisation of Bacillus cereus isolated from milk silo tanks at eight different dairy plants. Int Dairy J. 2004; 14(1): 17-27.

67. Brandl H, Fricker-Feer C, Ziegler, D., Mandal, J., Stephan, R., Lehner, A., 2014. Distribution and identification of culturable airborne microorganisms in a Swiss milk processing facility. J Dairy Sci. 97, 240-246.

68. Garnier L, Valence F, Mounier J. Diversity and Control of Spoilage Fungi in Dairy Products: An Update. Microorganisms. 2017; 5: 42.

69. Dworecka-Kaszak B, Krutkiewicz A, Szopa D, Kleczkowski M, Biegańska M. High Prevalence of Candida Yeast in Milk Samples from Cows Suffering from Mastitis in Poland. Sci World J. 2012; 196347.

70. Kim J, Sudbery P. Candida albicans, a major human fungal pathogen. J Microbiol. 2011; 49: 171.

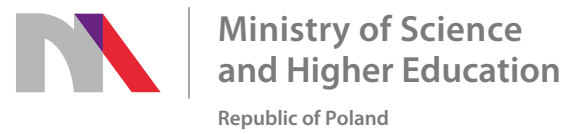

Generation of the DOI (Digital Object Identifier) - task financed under the agreement No. 618/P-DUN/2019 by the Minister of Science and Higher Education 